\title{
Analisis Metode Economic Order Quantity (EOQ) Dalam Upaya Meningkatkan Efisiensi Pada North Wood Coffee \& Eatery Bandung
}

\author{
Rizky Fadhyl, Caria Ningsih, Oman Sukirman \\ Manajemen Industri Katering, Fakultas Pendidikan Ilmu Pengetahuan Sosial, Universitas \\ Pendidikan Indonesia, Jl. Dr. Setiabudhi No. 229, Bandung 40154, Indonesia \\ *Koresponding Penulis. E-mail : rizkyfadhyl@gmail.com (Rizky Fadhly)
}

\begin{abstract}
Abstrak
Economic Order Quality (EOQ) adalah metode stockpile economic yang digunakan untuk menentukan jumlah pesanan perusahaan. Penelitian ini bertujuan untuk mengetahui perbandingan metode konvensional dan Economic Order Quality (EOQ) terkait dengan biaya efisiensi perusahaan di North Wood Coffee \& Eatery. Desain eksperimental dipilih sebagai metode dalam penelitian ini. Data primer dan sekunder digunakan sebagai analisis data. Kebutuhan dan biaya bahan baku perusahaan dalam rentang Oktober hingga Desember 2017 diambil sebagai data sekunder, sedangkan frekuensi pesanan, biaya pemesanan, dan biaya penyimpanan diambil sebagai data primer. Economic Order Quantity (EOQ) dan biaya efisiensi dari total persediaan digunakan juga sebagai alat analisis. Hasil penelitian menunjukkan bahwa metode Economic Order Quantity (EOQ) telah memberikan hasil yang signifikan pada biaya efisiensi dari total persediaan bahan baku di 80,24\% untuk bahan makanan dan 90,48\% untuk tahan lama. Singkatnya, jika Economic Order Quantity (EOQ) tercatat secara menyeluruh, Economic Order Quantity (EOQ) dapat diterapkan dengan cara yang benar. Economic Order Quantity (EOQ) diterapkan secara efektif untuk meningkatkan biaya efisiensi di North Wood Coffee \& Eatery.
\end{abstract}

Keywords: Economic Order Quantity (EOQ); Persediaan Bahan Baku; Biaya Persediaan; dan total biaya persediaan.

\section{Pendahuluan}

Pada era digital ini, perkembangan industri pariwisata di Indonesia mengalami perkembangan yang cukup pesat. Dengan adanya pariwisata, suatu Negara dapat mempromosikan Negaranya sehingga dapat memperoleh berbagai keuntungan yang dapat menunjang kesejahteraan bagi masyarakat di Negara tersebut.

Kota Bandung merupakan sebagai salah satu tujuan wisata dari berbagai masyarakat penjuru tanah air. Di kota Bandung ini orang dapat berbelanja dan menikmati kuliner bersama keluarga. Dan bisa dinikmati pula oleh pengunjung domestik bahkan ada beberapa yang datang dari Negara tetangga bahkan wisatawan mancanegara.

Seperti pada UU No.10 Tahun 2009 tentang kepariwisataan menyebutkan bahwa pariwisata adalah berbagai macam kegiatan wisata dan didukung oleh masyarakat, pengusaha, pemerintah dan pemerintah daerah. Daya tarik wisata adalah keanekaragamankekayaanalam, budaya, dan hasil buatan manusia yang menjadi sasaran atau tujuan kunjungan wisatawan.

Perkembangan pariwisata di Indonesia saat ini tentunya sangat memberi dampak positif bagi perekonomian Negara, bahkan termasuk beberapa daerah, sektor pariwisata merupakan jadi prioritas sumber pendapatan asli daerah. Sebagai salah satu wilayah yang merasakan peningkatan 
kunjungan wisatawan yang cukup signifikan yaitu pariwisata di Kota Bandung.

Salah satu contoh berkembangnya bisnis kuliner di Kota Bandung adalah banyaknya bermunculan Restaurant, Cafe, Foodcourt, bahkan sampai pedagang kaki lima.

Dengan semakin meningkatnya dan berkembangnya aneka ragam makanan dan konsumsi di Kota Bandung mengharuskan para pelaku bisnis kuliner harus bisa ber Inovasi mengikuti Trend kuliner saat ini dan dapat memenuhi pasar permintaan dari konsumen.

Pada suatu perusahaan baik dalam skala kecil, menengah maupun besar yang bergerak di dalam bidang apapun, harus memiliki sistem kontrol pada pengadaan bahan baku. Guna sistem kontrol tersebut ialah merupakan pencatatan - pencatatan terkait untuk jalannya suatu proses produksi. Mencatat hal - hal yang berkaitan dengan operasional perusahaan seperti pencatatan sebuah produk, bagaimana standar, berapa jumlah kapasitas produksi yang di gunakan, bagaimana cara pengadaan bahan baku, bagaimana cara pemesanan dari pihak konsumen ke pihak produsen, dan hal lain yang belum sepenuhnya bisa ber operasional atau bahkan belum dijalankan pada suatu perusahaan.

Untuk mencapai target omset pendapatan utama, perusahaan harus mempunyai sistem cost control (pengendalian biaya). Sistem ini merupakan tugas utama di bagian akunting, guna menjaga kestabilan pada suatu cost control (pengendalian biaya). Pengendalian biaya dibutuhkan sistem kontrol pada perseediaan bahan baku pada perusahaan. Dalam suatu perusahaan manufaktur khususnya bidang usaha kuliner, persediaan bahan baku merupakan aset utama pada perusahaan yang sangat memiliki pengaruh besar. Persediaan merupakan juga salah satu masalah yang cukup besar dan sensitif dalam suatu perusahaan. Persediaan dapat diartikan sebagai stock suatu barang atau product yang akan dijual atau suatu barang yang dapat digunakan pada jangka periode waktu tertentu. Persediaan juga dapat muncul secara disengaja maupun tidak disengaja bisa di artikan adanya perencanaan untuk pengadaan bahan baku yang dibutuhkan, Sedangkan yang tidak disengaja dapat diartikan persediaan masih tersedia karena ada bahan baku yang belum terjual akibat rendahnya jumlah pesanan atau permintaan. Data pengendalian persediaan barang dibutuhkan karena:

a. Ketika dalam waktu singkat suatu barang yang dibutuhkan tidak tersedia, sangat tidak memungkinkan bila dalam waktu yang singkat untuk mendatangkan barang apabila kebutuhannya berkali-kali, dengan jangka waktu yang tidak sedikit.

b. Kemungkinan akan sangat kecil untuk menghadirkan barang dalam waktu yang singkat untuk memenuhi kebutuhan produksi suatu product (produk). Dengan kekurangannya (out of stock) bahan baku dapat berakibat fatal dalam suatu perusahaan, yang akan berakibat terhentinya suatu proses produksi dan bisa membuat perusahaan kehilangan konsumennya, akan tetapi jika persediaan barang berlebih atau terlalu banyak (over stock) dapat mengakibatkan tingginya biaya penyimpanan dan pemeliharaan bahan selama persediaan di simpan digudang.

Oleh karena itu seharusnya ada kebijakan persediaan bahan baku yang harus diterapkan dalam suatu perusahaan dan biaya persediaan tersebut dapat ditekan seminimal mungkin. Untuk menekan guna menimalkan biaya persediaan maka dalam hal ini dapat digunakan metode "Economic Order Quantity" (EOQ). EOQ adalah volume atau jumlah pembelian yang paling ekonomis untuk dilakukan pada setiap kali perusahaan melakukan pembeliaan (Prawirosentono, 2000). Analisis perencanaan dengan menggunakan metode EOQ pada suatu perusahaan mampu mengurangi terjadinya out of stock ataupun over stock yang bisa mengganggu 
berlangsungnya proses produksi. Dengan dibuatnya suatu rancangan dengan metode EOQ, Suatu perusahaan dapat menekan biaya persediaan yang akan dikeluarkan oleh perusahaan. Dengan adanya analisis EOQ ini dapat digunakan dan diaplikasikan dengan praktis atau sangat mudah untuk merencanakan pembelian bahan baku dan menentukan kuantitas pembelian bahan baku.

Maka dengan digunakan metode perhitungan EOQ dapat keluar suatu titik minimum dan maksimum persediaan bahan baku. Persediaan yang dipesan paling datang. Tujuan diadakannya penentuan titik maksimum adalah agar dana anggaran pemborosan pada keuangan perusahaan. Karena saat produk yang sedang dipesan datang, jumlah produk yang ada di gudang penyimpanan perusahaan sama dengan ketersediaan atau sering juga disebut dengan istilah safety stock.

North Wood Coffee \& Eatery merupakan sebuah usaha menengah yang bergerak dalam bidang kuliner di kota Bandung, yang berdiri sejak 1 Mei 2014 berlokasi di Jl. Gegerkalong Hilir No. 179. Berawal dari pemanfaatan lahan kosong di halaman rumah. North Wood Coffe \& Eatery mempunyai konsep tempat ngopi bareng dengan suasana halaman rumah yang sangat cocok untuk berkumpul bersama kerabat, dengan menyajikan menu utama berbagai varian kopi, mie, pasta, dan roti.

Usaha ini berawal dari pemanfaatan lahan kosong yang hanya membuka semacam kios kecil serta beberapa meja dan bangku untuk konsumen yang di dominasi dengan furniture dari kayu tua dengan seiring waktu mulai berkembang menjadi suatu usaha menengah. Bahan baku yang banyak digunakan dalam proses produksi diantaranya yaitu kopi, mie, pasta serta roti dan dalam proses perlaksanaan sebuah produksinya bahan baku tersebut harus selalu tersedia untuk menunjang berjalannya proses produksi. Oleh karena itu harus dilaksanakan perencanaan dan pengendalian bahan baku untuk berlangsungnya proses produksi.

Perusahaan setidaknya harus bisa dalam mengelola persediaan bahan baku dengan baik agar dapat mengoptimalkan persediaan bahan baku, guna menunjang proses kelancaran produksi perusahaan. Berdasarkan dari pra penelitian yang telah dilakukan oleh peneliti, dalam pemenuhan kebutuhan bahan baku di North Wood coffe $\&$ eatery sangat perlu diperhatikan, karena pada sistem control pembelian, perencanaan dan pengendalian bahan baku di storage masih munggunakan sistem konfesional yaitu masih pencatatan secara manual.

Oleh sebab itu masih sering terjadi overstock dan out of stock pada persediaan bahan baku, akibat hal itu sering mengakibatkan biaya penyimpanan dan produksi menjadi tinggi.

Oleh sebab itu guna meningkatkan efisiensi laba North Wood Coffee \& Eatery memerlukan sistem control pembelian, perencanaan dan pengendalian bahan baku di storage, Serta perlu melakukan promosi lebih gencar lagi di social media agar meningkatkan pengunjung yang datang dan mulai mengadakan promosi - promosi menarik lainnya agar bisa menarik konsumen untuk datang berkelompok atau beramai - ramai sehingga dapat mencapai kriteria keuntungan yang di inginkan.

Dari uraian diatas maka penulis mengajukan beberapa permasalahan yakni sebagai berikut:

a. Bagaimana deskripsi persediaan dan biaya persediaan bahan baku di North Wood Coffee \& Eatery Bandung.

b. Bagaimana hasil dari metode Economic Order Quantity (EOQ) pada pembelian bahan baku terhadap total biaya persediaan bahan baku di North Wood Coffee \& Eatery Bandung.

c. Bagaimana pengaruhnyanya jika dilakukan perbandingan sistem pengendalian persediaan antara metode konfesional North Wood Coffe \& Eatery dengan metode Economic Order Quantity (EOQ).

d. Analisis tantangan \& peluang 
penerapan EOQ di North Wood Coffee \& Eatery?

\subsection{Pariwisata}

Definisi mengenai pariwisata yang dijelaskan dalam beberapa literatur, yaitu :

a. Pariwisata adalah suatu perjalanan yang dilakukan untuk sementara waktu yang diselenggarakan dari suatu tempat ke tempat lain, dengan maksud bukan untuk berusaha atau mencari nafkah ditempat yang dikunjungi, tetapi semata mata untuk menikmati perjalanan tersebut guna pertamasyaan dan rekreasi atau memenuhi keinginan yang beraneka ragam (Yoeti, 1996, hal 118)

b. Pariwisata merupakan pengalaman manusia yang menyenangkan dan membantu membuang rasa jenuh dari kehidupan sehari hari yang bersifat rutin dan membosankan (Happy marpaung, 2000, hal 13)

c. Dalam Undang Undang No. 10 tahun 2009 pada pasal 1 ayat 3, pariwisata adalah berbagai macam kegiatan wisata yang didukung berbagai fasilitas serta layanan yang disediakan oleh masyarakat, pengusaha, pemerintah dan pemerintah daerah.

d. Pariwisata adalah salah satu jenis industri baru yang mampu mempercepat pertumbuhan ekonomi dan penyediaan lapangan kerja, peningkatan penghasilan, standar hidup serta menstimulasi sektor-sektor produktif lainnya (Nyoman, 2006, hal 32)

Berdasarkan pengertian pariwisata diatas dapat menyimpulkan bahwa pariwisata merupakan aktifitas atau kegiatan manusia dalam kegiatan wisata untuk meminimalisir pengangguran yang didukung oleh masyarakat, juga pengusaha serta pemerintah daerah.

\subsection{Pengertian Restoran}

Restoran salah satu usaha yang banyak diminati pada saat ini, terutama di Bandung. Restoran tidak hanya dijadikan tempat makan namun tempat untuk bersantai sesuai dengan jenis-jenisnya. Menurut (Marsum WA, 1993, hal 7) restoran adalah suatu tempat atau bangunan yang diorganisasi secara komersial, yang menyelanggarakan pelayanan dengan baik kepada semua tamunya, baik berupa makan maupun minuman. Berikut ini merupakan klasifikasi restoran, diantaranya:

\section{a. Cafetaria}

Cafetaria merupakan sebuah industry jasa boga atau restauran yang menyediakan berbagai macam menu makanan maupun minuman yang ditata dalam display agar konsumen dapat langsung memilih menu yang diinginkan. Cafetaria tidak memiliki banyak karyawan karena menu yang di cafetaria hanya sedikit.

\section{b. Cepat Saji (Fast food)}

Industri rumah makan yang menawarkan menu makanan dan minuman yang mudah disajikan atau simple food \& beverage, dan juga menawarkan standart service yang cepat. Perkembangan jenis restoran cepat saji (Fast food) di Indonesia dapat berkembang dengan pesat dikarenakan banyaknya permintaan atau konsumen yang sangat butuh dengan sajian metode fast food restaurant. Contoh restoran cepat saji di Indonesia diantaranya yaitu KFC, McDonalds, dan Burger Kings.

\section{c. Coffee Shop}

Coffee Shop merupakan suatu tempat dimana mengandalkan atau mengutamakan menu minuman dan hanya menyajikan makanan ringan dengan harga yang dapat dijangkau oleh berbagai kalangan. Pada umumnya sistem pelayanan adalah dengan American service dimana yang diandalkan adalah kecepatan dalam pelayanannya.

\section{d. Family Restaurant}

Family Restaurant adalah suatu restoran sederhana yang menyediakan atau menghidangkan makanan dan minuman dengan harga yang terjangkau, terutama disediakan untuk tamu - tamu keluarga maupun rombongan lainnya. 


\subsection{Economic Order Quantity (EOQ)}

EOQ adalah suatu cara untuk memperoleh cara untuk memperoleh sejumlah barang dengan biaya minimum dan adanya pengawasan terhadap biaya pemesanan (Ordering Cost) dan biaya penympanan atau (Carrying Cost)" (Mannulang, 2005, hal. 70). Kemudian menurut Martono "Economic Order Quantity (EOQ) adalah jumlah barang yang dbeli dengan biaya persediaan yang minimum atau sering disebut jumlah pesanan yang optimal". Biaya persediaan dapat diminimumkan dengan memiliki jumlah pesanan yang optimal, yang disebut jumlah pesanan ekonomis (EOQ) (Martono, 2002, hal. 32)

Economic Order Quantity (EOQ) atau kuantitas pesanan ekonomis merupakan salah satu model klasik dalam suatu teknik pengendalian persediaan, hingga saat ini masih banyak yang mempergunakan metode EOQ karena mudah dalam penggunaannya. Pada metode EOQ, jumlah pesanan yang optimal akan muncul pada titik dimana biaya pemasangan total sama dengan biaya penahanan total (Heizer \& Render, 2010, hal. 321).

Dengan menggunakan variabel di bawah ini dapat menentukan biaya pemesanan dan penyimpanan agar didapatkannya nilai $\mathrm{Q}^{*}$ :

$\mathrm{Q}=$ Jumlah barang setiap pemesanan

$\mathrm{Q}^{*}=$ Jumlah optimal barang per pemesanan (EOQ)

$\mathrm{D}=$ Permintaan tahunan barang persediaan, dalam unit

$\mathrm{S}=$ Biaya pemasangan atau pemesanan untuk setiap pesanan

$\mathrm{H}=$ Biaya penahanan atau penyimpanan per unit per tahun

a. Biaya pemasangan tahunan $=$ (jumlah pesanan yang dilaukan per tahun)

(biaya pemasangan atau pemesanan setiap sekali pesan)

$=\left(\frac{\text { Permintaan tahunan }}{\text { Jumlah barang setiap pemesanan }}\right) \quad$ (biaya pemesanan atau pemasangan setiap pesanan)
$=\left(\frac{D}{Q}\right)(S)$

$=\frac{D}{Q} S$

b. Biaya penyimpanan tahunan = (tingkat persediaan rata - rata) (biaya penyimpanan per unit per tahun)

$$
\begin{aligned}
& =\left(\frac{Q}{2}\right) \\
& =\frac{Q}{2} \mathrm{H}
\end{aligned}
$$$$
=\left(\frac{\text { Jumlah pesanan }}{2}\right)
$$$$
\text { penyimpanan per unit per tahun) }
$$

(biaya

c. Jumlah pesanan optimal ditentukan pada saat biaya pemasangan sama dengan biaya penyimpanan tahunan, yaitu :

$$
=\frac{D}{Q} s=\frac{Q}{2} \mathrm{H}
$$

d. Untuk mendapatkan nilai $\mathrm{Q}^{*}$, maka dilakukan perkalian silang dan pisahkan $Q$ di sebelah kiri tanda sama dengan.

$$
\begin{aligned}
& 2 \mathrm{DS}=\mathrm{Q}^{2} \mathrm{H} \\
& \mathrm{Q}^{2}=\frac{2 D S}{H} \\
& \mathrm{Q}^{*}=\sqrt{\frac{2 D S}{H}}
\end{aligned}
$$

Dapat pula menetapkan jumlah pemesanan yang ingin dibuat sepanjang tahun $(\mathrm{N})$ dan waktu yang diinginkan antar pemesanan $(\mathrm{T})$, sebagai berikut : Jumlah pemesanan yang diinginkan :

$$
N=\frac{\text { Permintaan }}{\text { Jumlah unit yang dipesan }}=\frac{D}{Q^{*}}
$$

Jumlah waktu antar pemesanan yang di inginkan :

$$
T=\frac{\text { Jumlah hari dalam setahun }}{N}
$$

\subsection{Keunggulan Serta Kelemahan Metode EOQ}

$$
\text { Kartika Hendra }
$$

mengemukakan bahwa keunggulan EOQ adalah:

a. Dapat digunakan untuk mengetahui berapa banyak bahan baku yang harus di pesan, dan kapan pemesanan seharusna dilakukan.

b. Dapat mengatasi ketidakpastian permintaan dengan adanya persediaan pengaman (Safety Stock).

c. Mudah diaplikasikan pada proses 
produksi secara masal.

d. Lazimnya digunakan di rumah sakit, yaitu pada persediaan obat.

Dengan menggunakan metode EOQ terdapat beberapa kekurangan yang membuat proses produksi terganggu, hal tersebut terjadi dikarenakan kurang eratnya hubungan relasi perusahaan dengan pemasok, karena metode EOQ menempatkan pemasok sebagai mitra bisnis yang sifatnya sementara, karena para pemasok menerapkan paradigma untung rugi, dengan demikian model EOQ akan memaksa perusahaan untuk sering berganti pemasok baru.

\section{Metode Penelitian}

Penelitian ini dilakukan untuk menganalisis persediaan bahan baku kopi dengan menggunakan metode Economic Order Quantity (EOQ). Objek penelitian yang digunakan terdiri dari variabel Independent (variabel bebas) yaitu metode Economic Order Quantity (X) dan variabel Dependent (variabel terikat) yaitu efisiensi biaya persediaan bahan baku (Y). Sedangkan subjek dari penelitian adalah perusahaan North Wood Coffee \& Eatery yang terletak di Jl. Gegerkalong Hilir No. 179, Kota Bandung. North Wood Coffee \& Eatery merupakan usaha kuliner yang fokus pada minuman yang berbahan dasar dari kopi atau bisa juga di golongkan ke dalam coffee shop. Northwood juga memproduksi makanan dan minuman dari mulai merencanakan bahan baku, produksi, hingga pelayanan kepada konsumen.

Penelitian yang akan dilakukan oleh penulis yaitu dengan menggunakan cara menganalisis perencanaan kebutuhan bahan baku yang dilakukan oleh North Wood Coffee \& Eatery Dengan cara memahami karakteristik dan persediaan yang digunakan pada usaha coffee shop tersebut.

Mengidentifikasi terlebih dahulu suatu permintaan merupakan karakteristik produksi serta persediaan pada suatu perusahaan. Kemudian setelah mengetahui jumlah kebutuhan produksi dan persediaan, penulis juga harus mengetahui berapa jumlah dari permintaannya, setelah itu harus diterjemahkan kedalam suatu analisa perencanaan bahan baku.

Penelitian ini bersifat modeling atau penerapan suatu sistem yang sering digunakan dalam industri manufaktur (industri skala besar) kedalam skala kecil yaitu industri jasa boga. Kemudian hasil akhir daripada penelitian ini akan dibandingkan dengan perencanaan kebutuhan bahan baku untuk mengetahui apakah suatu metode EOQ yang biasa digunakan pada industri skala besar dapat diimplikasikan pada industri skala kecil. Dengan bentuk pre- experimental design yaitu one group pretest-postest design. Dengan demikian hasil perlakuan dapat diketahui lebih akurat karena dapat membandingkan dengan keadaan sebelum diberikan perlakuan.

Adapun desain ini dapat digambarkan sebagai berikut menurut (Sugiyono, 2012, hal. 75) :

$\mathbf{0}_{\mathbf{1}}=$ Hasil perhitungan yang sudah berjalan

\section{$\mathbf{0}_{2}=$ Hasil perhitungan manual}

Sehingga metode penelitian yang digunakan adalah metode penelitian kuantitatif. Dengan pengujian hipotesis yang telah diajukan yaitu hipotesis komparatif (uji perbedaan).

\section{Hasil dan Pembahasan}

Uji efisiensi biaya persediaan total adalah uji yang dilakukan untuk melihat seberapa efektif mode yang digunakan terhadap proses control yang telah dilakukan oleh penulis dengan cara menguji selisih antara metode konfesional North Wood Coffee \& Eatery dengan metode EOQ. Hal tersebut dapat dibuktikan pada tabel dibawah ini: 
Tabel 1. Perbandingan Total Biaya Persediaan berdasarkan Metode Konfensional North Wood Coffee \& Eatery dan Metode Economic Order Quantity (EOQ)

\begin{tabular}{|c|r|c|c|c|}
\hline \multirow{2}{*}{ Material } & \multicolumn{2}{|c|}{ Total Biaya Persediaan } & \multirow{2}{*}{ Selisih } & $\begin{array}{c}\text { Sistem } \\
\text { Paling }\end{array}$ \\
\cline { 2 - 3 } & $\begin{array}{c}\text { Metode } \\
\text { Perusahaan(Rp) }\end{array}$ & $\begin{array}{c}\text { Metode } \\
\text { EOQ(Rp) }\end{array}$ & $(\mathrm{Rp})$ & Economic \\
\hline Groceries & $8,854,962.02$ & $1,749,306.57$ & $7,105,655.45$ & EOQ \\
\hline Perishable & $2,959,054.93$ & $281,700.48$ & $2,677,354.45$ & EOQ \\
\hline
\end{tabular}

Sumber: Data North Wood Coffee \& Eatery yang di olah, 2018

Setelah dilakukannya proses perbandingan total biaya persediaan maka dapat dibuktikan metode Economic Order Quantity (EOQ) lebih ekonomis dibandingkan dengan konfensional yang digunakan North Wood Coffee \& Eatery.

Metode EOQ memberikan efisiensi biaya persediaan total bahan baku groceries sebesar $80,24 \%$ dan bahan baku perishable sebesar $90,48 \%$.

\section{Kesimpulan}

Setelah dilakukan pendataan dan proses pengolahan data, Maka dapat disimpulkan bahwa ketersediaan bahan baku pada perusahaan jasa kuliner menjadi faktor penentu dalam berlangsungnya proses produksi. Pengendalian persediaan merupakan kegiatan yang sangat penting dalam sebuah perusahaan karena dapat berpengaruh terhadap efisiensi biaya, kelancaran dalam proses produksi maupun bagi keuntungan proses usaha itu sendiri.

North Wood Coffee \& Eatery merupakan cafe yang dapat memenuhi kebutuhan tamu, baik itu makanan ataupun minuman. North Wood Coffee \& Eatery membuat perencanaan untuk memenuhi kebutuhan bahan baku dengan metode konfensional yaitu metode asumsi atau perkiraan. Maka dalam penelitian ini penulis mencova untuk membuat perbandingan antara metode konfensional dengan metode Economic Order Quantity (EOQ). Kesimpulan atas penilitian guna untuk pemenuhan jawaban berdasarkan rumusan masalah, yaitu: a. Gambaran persediaan dan biaya persediaan bahan baku pada North Wood Coffee \& Eatery Bandung

Bahan baku North Wood Coffee \& Eatery pada periode bulan oktober desember 2017 terdiri dari bahan baku groceries dan bahan baku perishable. Bahan baku groceries terdiri dari 50 item dan bahan baku perishable terdiri dari 14 item. Kelompok bahan baku groceries terdiri dari beef, poultry, dairy, cheese, sugar, pantry, supplies, flours product \& rice. Bahan baku perishable terdiri dari 14 item yaitu roti tawar, pisang, french fries, lemon, jambu, sirsak, selada, timun, cabe domba, tomat, udang, cumi, balakutak, tuna.

Biaya persediaan bahan baku North Wood Coffee \& Eatery terdiri dari biaya penyimpanan dan komponen biaya pesan. Biaya pemesanan setiap bahan baku adalah sebesar Rp 10.404,62 per bulan serta biaya penyimpanan setiap item bahan baku adalah $2 \%$ dari harga item. Total biaya persediaan didapatkan dari penjumlahan total biaya penyimpanan dan total biaya pemesanan selama satu periode. Total biaya persediaan bahan baku groceries menurut perusahaan adalah $\mathrm{Rp}$ 8.854.962,02 dan bahan baku perishable Rp 2.595.054,93.

b. Impilaksi metode Economic Order Quantiry (EOQ) dalam pembelian bahan baku terhadap total biaya persediaan bahan baku pada North Wood Coffee \& Eatery Bandung.

Pengadaan bahan baku pada North Wood Coffee \& Eatery menggunakan metode EOQ menyebabkan adanya perbedaan terhadap pembelian bahan baku, frekuensi pemesanan dan jangka waktu pemesanan. Maka dengan adanya perbedaan tersebut berpengaruh terhadap pada cara perhitungan total biaya pemesanan, total biaya penyimpanan dan total biaya persediaan.

Berdasarkan penelitian yang telah dilaksanakan oleh penulis di North Wood Coffee \& Eatery Bandung, Menunjukan bahwa implikasi metode EOQ dalam pembelian bahan baku terhadap total biaya 
persediaan baku pada North Wood Coffee \& Eatery Bandung dapat diterapkan. Diamna dengan menggunakan metode EOQ total biaya persediaan bahan baku groceries sebesar Rp 1.749.306,57 dan pada bahan baku perishable $\operatorname{Rp} 281.700,48$.

c. Implikasi metode perusahaan North Wood Coffee \& Eatery Bandung dibandingkan dengan menggunakan metode EOQ dalam pembeliaan bahan baku terhadap efisiensi total biaya persediaan bahan baku pada North Wood Coffee \& Eatery.

Berdasarkan hasil penelitian yang dilakukan di North Wood Coffee \& Eatery Bandung, aplikasi metode lebih efisien dibandingkan dengan metode perusahaan dalam efisiensi total biaya persediaan bahan baku selama periode Oktober - Desember 2017. Total biaya persediaan bahan baku groceries yang semula sebesar Rp 8.854.962,02 menjadi $\mathrm{Rp} 1.749 .306,57$ dengan selisih Rp 7.105.655,45. Sedangkan pada total biaya persediaan bahan baku perishable yang semula $\mathrm{Rp} 2.959 .054 .93$ menjadi Rp 281.700.48 dengan selisih $\mathrm{Rp}$ 2.677.354,45. Dapat disimpulkan efisiensi biaya persediaan menjadi $80,24 \%$ untuk bahan baku groceries dan $90.48 \%$ untuk bahan baku perishable.

d. Tantangan dan Peluang penerapan Economic Order Quantity (EOQ) pada North Wood Coffee \& Eatery.

Berdasarkan hasil penelitian yang dilakukan pada North Wood Coffee \& Eatery Bandung, tantangan utama penerapan metode Economic Order Quantity (EOQ) di North Wood Coffee \& Eatery adalah pengendalian yang ketat pada barang yang datang, pengendalian yang efektif pada semua barang yang keluar dari storage, pemilihan karyawan yang professional atau orang yang ahli didalam bidangnya dan pelatihan karyawan, pembuatan bin card, pendisiplinan dan pelaksanaan SOP (Standar Operasional Prosedur). Adapun peluang terbesar penerapan EOQ yang bisa memberikan keuntungan bagi pihak North Wood Coffee
\& Eatery adalah penghematan total biaya persediaan, menentukan jumlah pemesanan bahan baku yang optimal dan meningkatkan profit. Metode Economic Order Quantity (EOQ) dapat segera diterapkan dan berjalan dengan lancar apabila semua pencatatan terkait pembuatan metode EOQ tersedia.

\section{Daftar Pustaka}

Heizer, Jay, and Barry Render. (2010). Operations Management. Jakarta: Salemba Empat.

Manullang, Marihot \& Sinaga, Dearlina. (2005). Pengantar Manajemen Keuangan. Yogyakarta: Andi Offset

Marpaung, H., D. S. (2000). Pengetahuan Kepariwisataan. Bandung: ALFABETA.

Marsum. (1993). Restoran dan Segala Permasalahannya. Yogyakarta: Andi Offset.

Martono, Hartito. (2002). Manajemen Keuangan. Edisi Pertama. Yogyakarta: Ekonisia

Pendit, S. Nyoman (2006). Pariwisata. Jakarta: PT. Praddnya Paramita

Prawirosentono, S. (2000). Manajemen Operasi : Analisis dan Studi Kasus. Jakarta: Bumi Aksara.

Sugiyono. (2012). Matode penelitian Kuantitatif, kualitatif dan $R \& D$. Bandung: Alfabeta.

Undang - Undang Republik Indonesia No.10 Tahun 2009 Tentang Kepariwisataan.

Yoeti, O, A. (1996). Pengantar Ilmu Pariwisata. Bandung: Angkasa. 